\title{
ROAD TO REDEMPTION
}

The Liberal Party of Canada, 2006-2019 
This page intentionally left blank 


\section{BROOKE JEFFREY}

\section{Road to Redemption}

The Liberal Party of Canada, 2006-2019 
(C) University of Toronto Press 2021

Toronto Buffalo London

utorontopress.com

Printed in Canada

ISBN 978-1-4875-0056-6 (cloth)

ISBN 978-1-4875-1131-9 (EPUB)

ISBN 978-1-4875-1130-2 (PDF)

\section{Library and Archives Canada Cataloguing in Publication}

Title: Road to redemption : the Liberal Party of Canada, 2006-2019 /

Brooke Jeffrey.

Names: Jeffrey, Brooke, author.

Description: Includes bibliographical references and index.

Identifiers: Canadiana (print) 20200307681 | Canadiana (ebook)

20200307746 | ISBN 9781487500566 (hardcover) | ISBN 9781487511319

(EPUB) | ISBN 9781487511302 (PDF)

Subjects: LCSH: Liberal Party of Canada. | LCSH: Political parties -

Canada. | CSH: Canada - Politics and government - 2006-2015. |

CSH: Canada - Politics and government - 2015-

Classification: LCC JL197.L53 J44 2020 | DDC 324.27106 - dc2

University of Toronto Press acknowledges the financial assistance to its publishing program of the Canada Council for the Arts and the Ontario Arts Council, an agency of the Government of Ontario.

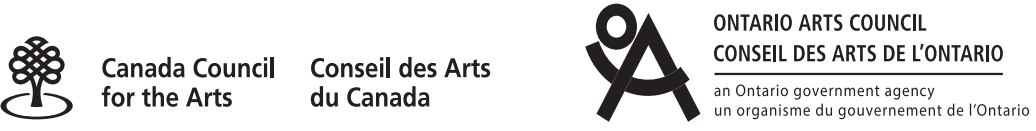

$\begin{array}{r}\text { Funded by the } \\ \text { Government } \\ \text { of Canada }\end{array} \begin{array}{r}\text { Financé par le } \\ \text { du Canementa }\end{array}$ 
For Ian, Devon, and Chris 
This page intentionally left blank 